\title{
Remittances and Inflation in Egypt: An Econometric Study Using an ARDL Model
}

\author{
Waleed Mohamed Youssef \\ Lecturer of Economics \\ Faculty of Business - Ain Shams University \\ Arab Republic of Egypt \\ waleed.youssef@bus.asu.edu.eg
}

\begin{abstract}
This paper analyzes the impact of remittance inflows on inflation in Egypt. It uses an Autoregressive Distributed Lag (ARDL) model to identify the short-run and long-run sources of inflation in Egypt during 19752019, while including remittance inflows among the inflation determinants. The results show that remittance inflows to Egypt have inflationary pressures in the long run, whereas such inflationary pressures are not confirmed in the short run. Other sources of inflation in the long run include the output gap, money supply, and openness. The results indicate the exchange-rate pass through effect is transitory, since it exists only in the short run.
\end{abstract}

Keywords: Remittances, Inflation, Cointegration, Autoregressive Distributed Lag Model, Error Correction Model.

\section{Introduction}

Remittances have several positive economic effects on the recipient countries both at the micro and macro levels as illustrated by empirical evidence. At the micro level, remittance inflows can help smooth household consumption, provide better education opportunities, and provide insurance for families against unemployment, illness, accidents, and disability. At the macro level, remittance inflows can boost national economies by stimulating aggregate demand through increased consumption, increasing inflows that can be invested in productive sectors, providing foreign currency inflows, and stabilizing balance of payments accounts in countries with structural trade deficit (Sharaf, 2014).

The relative importance of remittance inflows to Egypt has been rising since the 1970s. Such relative importance stems from the growing role played by remittances as source of foreign exchange in the Egyptian economy. Meanwhile, remittance inflows represent a relatively stable source of foreign exchange to Egypt compared to exports and net FDI inflows (Zahran, 2019). In this regard, Egypt has been ranked fifth among the top remittance-receiving countries in 2019 based on the World Bank with an amount of US\$2 26.78 billion compared to just US\$ 0.825 billion in 1975.

However, several empirical studies have argued that remittance inflows might have inflationary pressures on the receiving countries due to Dutch Disease effects, reduced incentives to work by emigrant's family members, or increased consumption expenditure on the receiving countries mainly on imports (Acosta et al., 2009; Iqbal et al., 2013; Ngoc and Nguyen, 2014). In this context, there is a lack of the empirical studies that

* This article was submitted in August 2021, and accepted for publishing in November 2021.

(C) Arab Administrative Development Organization- League of Arab States, 2024, pp 295-308، DOI: 10.21608/aja.2021.93493.1146 
investigate the effect of remittance inflows on inflation in Egypt, and hence this paper will try to cover this research gap by tackling the research question of whether remittance inflows have inflationary or deflationary effects on the Egyptian economy.

This paper differs from the previous empirical studies on the determinants of inflation in Egypt, since it includes remittances among the inflation determinants while using ARDL cointegration approach to identify sources of inflation in Egypt during 1975-2019. The data involved are annual to cover the period starting from the mid-1970s, as quarterly data for remittance inflows are not available for the 1970s and the 1980s.

The rest of the paper is organized as follows: section (2) reviews the theoretical and empirical literature related to the effect of remittance inflows on inflation, while section (3) presents the trend and determinants of inflation in Egypt. Section (4) sets the methodology focusing on data, model specification, and the adopted econometric technique. Section (5) presents and discusses the model results, and section (6) concludes and presents recommemdations.

\section{Literature Review}

Literature review will start with a theoretical review of the causes or determinants of inflation followed by a review of the impact of remittances on inflation in theory. This theoretical review is then complemented with the empirical evidence on the relationship between remittances and inflation.

\section{Theoretical Background}

The theoretical analysis of the relationship between remittances and inflation will start with a discussion of the evolution of the causes of inflation in theory, before focusing on the impact of remittances on inflation in theory.

\section{1- Inflation Determinants in Theory}

Inflation causes or determinants have been considered among the controversial issues in economic theory since the classical theory. Classical and neoclassical economists argued that inflation is caused by monetary growth. They adopted the quantity theory of money in its different forms to argue that the price level changes proportionally with the money supply given that real output is predetermined in the classical and neoclassical theories by the supply factors and is assumed to be at the full employment level, while the velocity of money is assumed to be constant in the short run, and hence, inflation is monetary in its nature and is considered a demand-pull inflation according to classical and neoclassical economists (Froyen, 2013).

By the early 1930s, John Maynard Keynes criticized the quantity theory of money for assuming that the velocity of money is constant. Conversely, Keynes adopted the liquidity preference theory to argue that the amount of money held by economic agents depends on the change in the interest rate on bonds, and thus, the velocity of money might unpredictably change and offset the change in money supply, and in such a case, the price level might not change with the change in money supply (Snowdon and Vane, 2005). However, Keynes used an inflationary gap model with wage rigidities in the short run to show that an exogenous increase in aggregate demand will result in inflationary pressures given that the economy was at its full employment level. In this way, it appears that the Keynesian explanation of inflation was also a demand-side one, but it differs from that of the classical and neoclassical economists as the Keynesian theory was a non-monetary demand-pull inflation theory (Kibritçioğlu, 2002).

By the late 1950s, the neo-keynesian economists started to investigate empirically the relationship between inflation and unemployment. Among those economists was Alban Williams Phillips, who used 
the IS-LM model to argue that there is a long run trade-off between inflation $(\pi)$ and unemployment $(U)$, as represented by the following traditional Phillips-curve equation, considering that the original form of this equation was expressed using the change in money wage rate rather than inflation rate (Phillips, 1958):

$$
\pi_{\mathrm{t}}=\alpha(\mathrm{U})-\ldots(1)
$$

Phillips interpreted any decrease in unemployment as an excess demand for labor, and hence, an excess demand in the goods market resulting in demand-pull inflation. In this sense, there is an inverse relationship between inflation and unemployment that was also confirmed by Lipsey (1960) as well as Samuelson and Solow (1960).

Nevertheless, the trade-off suggested by the Phillips curve was challenged in the late 1960s and early 1970 s as it was unable to explain the existence of both inflation and unemployment, i.e., stagflation in the US economy. In this regard, the monetarists led by Milton Friedman and Edmund Phelps criticized the traditional Phillips curve and alternatively suggested the expectations-augmented Phillips curve (Kibritçioğlu, 2002). According to Friedman (1968), the inflation equation using the expectations-augmented Phillips curve can be expressed as:

$$
\pi_{\mathrm{t}}=\alpha(\mathrm{U})+\beta \pi_{\mathrm{t}}^{\mathrm{e}} \quad-\cdots(2)
$$

The above equation implies that Friedman explained the inflation rate at period t by changes in the unemployment rate in that period and the expected rate of inflation in period $t\left(\pi_{\mathrm{t}}^{\mathrm{e}}\right)$. In this expectations-augmented Phillips curve approach, there will be more than one short run Phillips curve, and each is associated with a different expected rate of inflation and there will be a negative relationship between inflation and unemployment in the short run. However, as the economic agents adapt to their inflation expectations, the economy will move towards its natural rate of unemployment in the long run, and there will not be any long run trade-off between inflation and unemployment, and thus, the long run Phillips curve is vertical according to the monetarists (Froyen 2013).

In the context of the expectations-augmented Phillips curve, the monetarists believed that inflation expectations are backward looking or adaptive, arguing that the economic agents form their inflation expectations based on past inflation, as represented by the following equation:

$$
\pi_{\mathrm{t}}^{\mathrm{e}}=\lambda \pi_{\mathrm{t}-1}+(1-\lambda) \pi_{\mathrm{t}-1}^{\mathrm{e}}
$$

Based on equation (3), the expected rate of inflation in period $t$ is a weighted average of the actual inflation rate and the expected inflation rate in the previous time period, $\mathrm{t}-1$. This equation is adopted by some economists to measure and account for inflation persistence or inertia.

Unlike the monetarist explanation of inflation as a monetary phenomenon, another theoretical strand emerged in the 1970s and explained inflation as a cost-push issue that is caused by supply-side factors that raise the general price level. Among these supply-side factors are the rise in oil prices, the depreciation in the value of domestic currency, or the rise in import prices. The cost-push theories were led by the structuralists who related inflation to country-specific structural factors such as the productivity differences between agricultural and industrial sectors. Furthermore, the second generation of the new classical theory appeared in the 1980s and was known as the real business cycle (RBC) theory, as they gave much more importance to the role of negative supply shocks such as slowing aggregate productivity, rise in oil or food prices, bad weather, and domestic currency in explaining inflation (Kibritçioğlu, 2002).

Following this development in the inflation theory, Gordon (1990) suggested an inflation triangle model that explains inflation by three main factors, which are demand, supply, and inflation persistence. This model was considered by Gordon as the modern Phillips curve and can be represented as: 


$$
\pi_{\mathrm{t}}=\sum \alpha_{\mathrm{j}} \pi_{\mathrm{t}-\mathrm{j}}+\sum \beta_{\mathrm{i}}\left(\mathrm{Y}_{\mathrm{t}-\mathrm{i}}-\mathrm{Y}^{*}\right)+\theta \mathrm{Z}_{\mathrm{t}-\mathrm{i}}
$$

In the above equation, $\pi_{t-i}$ is the lagged inflation that is used as a proxy for inflation persistence, $\left(\mathrm{Y}_{\mathrm{t}-\mathrm{i}}\right.$ $-Y^{*}$ ) represents the output gap that is a proxy for demand, while $Z$ represents other control variables including supply shocks. In this model, inflation stems from three possible determinants which are the rise in inflation persistence, the positive output gap implying that actual output $(Y)$ is exceeding the potential output $\left(Y^{*}\right)$, and negative supply shocks (Benkovskis el al., 2011). Gordon's triangle model represents a synthesis of the theoretical views regarding inflation determinants and causes, and hence, this model can be used to investigate inflation determinants empirically.

\section{2- Remittances and Inflation in Theory}

In line with the above investigation of the determinants of inflation in theory, remittances have been considered among the capital inflows that might have inflationary or deflationary effects in an economy. On the one hand, remittances can lead to inflation through three main channels, namely, aggregate demand, foreign reserves, and real exchange rate.

First, remittance inflows can fuel inflation through their demand-side effects. When remittances increase, the aggregate demand increases resulting in increased consumption. If such increase in in consumption is not accompanied with a rise in the supply of goods and services, the result will be inflationary pressures. This demand-side inflation will take place mainly in countries with supply-side bottlenecks and in which remittances flow mainly for altruistic motives, given that remittances for altruistic motives are largely directed towards consumption in the recipient countries (Iqbal et al., 2013).

Second, remittance inflows can result in inflationary pressures through their effects on foreign reserves. In this regard, an increase in remittances will increase the supply of foreign currency in the recipient country, and thus, result in an increase in the domestic money supply. Such rise in domestic money supply will, in turn, result in demand-pull inflation, particularly if the central bank fails to fully sterilize this excess supply of foreign currency, and this will likely occur in countries that adopt a fixed exchange rate regime (Ngoc and Nguyen, 2014).

Finally, remittance inflows can cause inflation through their impact on the real exchange rate. In this context, an increase in remittances will increase household income and aggregate demand with a bias towards consumption of nontradables such as real estate and services at the expense of tradable goods. If the supply of nontradables is limited by resource availability, the prices of nontradables will rise (Cáceres and Saca, 2006). Moreover, since remittances will increase household income, remittance inflows might reduce the work incentives and decrease the labor supply in the recipient country resulting in higher wages and hence, a rise in production costs of the nontradables which are relatively labor intensive, and this in turn will also lead to a rise in the prices of the nontradables. As a result of this rise in the prices of the nontradables, there will be a resource shift from the tradable to the nontradable sector and thus, a contraction in the tradable sector which will cause an appreciation in real exchange rate and inflationary pressures, and this phenomenon is known as the Dutch Disease effects (Acosta et al., 2009).

On the other hand, remittance inflows can lead to deflationary pressures. Such deflationary pressures might be the result of the increase in resources directed towards investment and production in the recipient country, which in turn, will result in an increase in the supply of goods and services, and thus, downward pressures on prices (Iqbal et al., 2013).

In addition, remittance inflows will result in a flow of foreign currency into the recipient country causing an appreciation in the domestic currency. This rise in the value of the domestic currency will reduce the costs of imports and therefore, decrease inflationary pressures in countries that depend largely on imports. 
Such deflationary pressures of remittance inflows will be apparent if the recipient country is adopting a flexible exchange rate regime (Ball et al., 2013).

\section{Empirical Evidence}

The relationship between remittances and inflation has been largely investigated by several empirical studies using time-series or panel data of the remittance-recipient countries. In this regard, the studies have followed two different approaches. The first approach focuses on studying the impact of remittances on inflation by examining the Dutch Disease effects of remittances, while the other one includes remittances among the inflation determinants in the recipient country. Accordingly, this sub-section will focus on reviewing the empirical studies that followed these two different approaches.

The first strand of empirical studies investigated the Dutch Disease effects of remittance inflows by estimating the effect of remittances on the real exchange rate in the recipient countries. In this context, Amuedo-Dorantes and Pozo (2004) studied the impact of remittances on the real exchange rate for a panel of 13 Latin American countries during 1979-98 using fixed-effects ordinary least squares (OLS) estimators while controlling for some variables. Amuedo-Dorantes and Pozo found that remittances appreciated the real exchange rate in the recipient countries and caused inflationary pressures.

Moreover, Cáceres and Saca (2006) used a vector autoregressive (VAR) model with monthly data to investigate the impact of remittances on the real exchange rate in El Salvador during 1995-2004. Cáceres and Saca argued that remittances have appreciated the real effective exchange rate (REER) and resulted in a rise in the prices of the nontradables, and hence, a resource shift from the tradable to the non-tradable sectors with a reduction in the competitiveness of the exports of the tradable sector.

Following the same approach, Lartey et al. (2008) studied the Dutch Disease effects of remittances for a panel of 109 developing and transition countries, including Egypt, during 1990-2003 using dynamic generalized method of moments (GMM) estimators. They found also that remittances have resulted in Dutch Disease effects and that such effects have been stronger in countries with fixed exchange rate regimes.

The other strand of empirical studies examined the impact of remittances by including remittance inflows among the determinants of inflation in the recipient country. For instance, Balderas and Nath (2008) estimated the effect of remittances on inflation and relative price variability in Mexico using a VAR model with monthly data during 1995-2005, while including some other inflation determinants. Balderas and Nath argued that there is a positive relationship between inflation and relative price variability, and they suggested that remittances might have resulted in inflation, since the majority of remittance inflows to Mexico are spent on consumption rather than investment.

Alternatively, Narayan et al. (2011) investigated the determinants of inflation for a panel of 54 developing countries, including Egypt, during 1995-2004 using system and differenced GMM estimators. They found that remittances had a positive impact on inflation in the long run, given that the positive impact of remittances on inflation was not so much apparent in the short run. The results of this study imply that remittances are mostly directed towards consumption in developing countries, particularly those remittance inflows that are altruistically motivated.

Furthermore, Nisar and Tufail (2013) adopted Johansen cointegration test with a Vector Error- Correction Model (VECM) to analyze the inflation determinants in Pakistan during 1970-2010. Nisar and Tufail also argued that remittances have affected inflation positively. Among the inflation categories, food inflation was the most positively affected whereas housing and construction inflation was the least positively affected by remittances. Similarly, Khan and Islam (2013) found that remittances have caused long-run inflationary pressures in Bangladesh during 1972-2010 using Johansen cointegration test with a VECM. 
Nevertheless, Khan and Islam found argued that there was no significant relationship between remittances and inflation in the short run.

The relationship between remittances and inflation had been also investigated by Abdul-Mumni and Quaido (2016) who adopted the bounds testing approach with an Autoregressive Distributed Lag (ARDL) model and showed that remittances had a long-run positive inflationary effect in Ghana during 1979-2013. However, the results showed that there was no significant relationship between remittances and inflation in the short run.

Unlike the results of most empirical studies, Rivera and Tuallo Jr. (2020) argued that remittances were not necessarily inflationary in Philippines during January 2000-October 2019 using a VAR model. Rivera and Tuallo Jr. found that the impact of any shock in remittances on inflation was absorbed in the short run, implying that there is no relationship between remittances and inflation.

From the above empirical review, it appears that most of empirical studies concluded that remittance inflows have inflationary pressures in the recipient countries. Meanwhile, the studies found that these inflationary pressures depend on some factors such as whether remittances are spent on consumption or investment in the recipient country, the motives for sending remittances are altruistic or related to self-interest of the migrant, and whether the adopted exchange rate regime in the recipient country is fixed or flexible.

\section{Remittances and Inflation in the Egyptian Economy}

Remittances are considered an important source of foreign exchange in the Egyptian economy and hence, play a major role in affecting economic growth and development in several ways. This section will firstly emphasize the relative importance and determinants of remittance inflows to Egypt, and then will investigate the main determinants of inflation in Egypt according to empirical literature.

\section{Relative Importance and Determinants of Remittance Inflows to Egypt}

The relative importance of remittance inflows to Egypt has increased since the 1970s with the rising trend of emigration, mainly the emigration of Egyptian workers to the Gulf countries. In this regard, the number of Egyptian emigrants has increased by about three times from 1.3 billion in 1990 to 3.6 billion in 2019, which makes Egypt ranked the $19^{\text {th }}$ among the top origin countries of international migrants in 2019 according to the United Nations Department of Economic and Social Affairs (UN-DESA).

Here, remittances are defined to include both personal transfers and compensation of employees as defined in the Sixth edition of the IMF's Balance of Payments Manual. According to this definition, personal transfers consist of all current transfers in cash or in kind made or received by resident households to or from nonresident households, whereas compensation of employees refers to the income of border, seasonal, and other short-term workers who are employed in an economy where they are not resident and of residents employed by nonresident entities (IMF, 2009).

According to the World Development Indicators (WDI) by the World Bank, remittance inflows to Egypt have grown substantially since the 1970s reaching US\$26.78 billion in 2019 compared to US $\$ 0.825$ billion in 1975. As a percentage of gross domestic product (GDP), remittances represented $8.8 \%$ in 2019 compared to $7.1 \%$ in 1975 . Moreover, Egypt was ranked the fifth among the top remittance-recipient countries in 2019 after India, China, Mexico, and the Philippines according to the World Bank.

The rising importance of remittances in the Egyptian economy stems from being an important source of foreign exchange. Figure (1) shows that remittances as a \% of GDP come after exports as a source of foreign exchange followed by net foreign direct investment (FDI) flows and official development assistance (ODA) flows. 


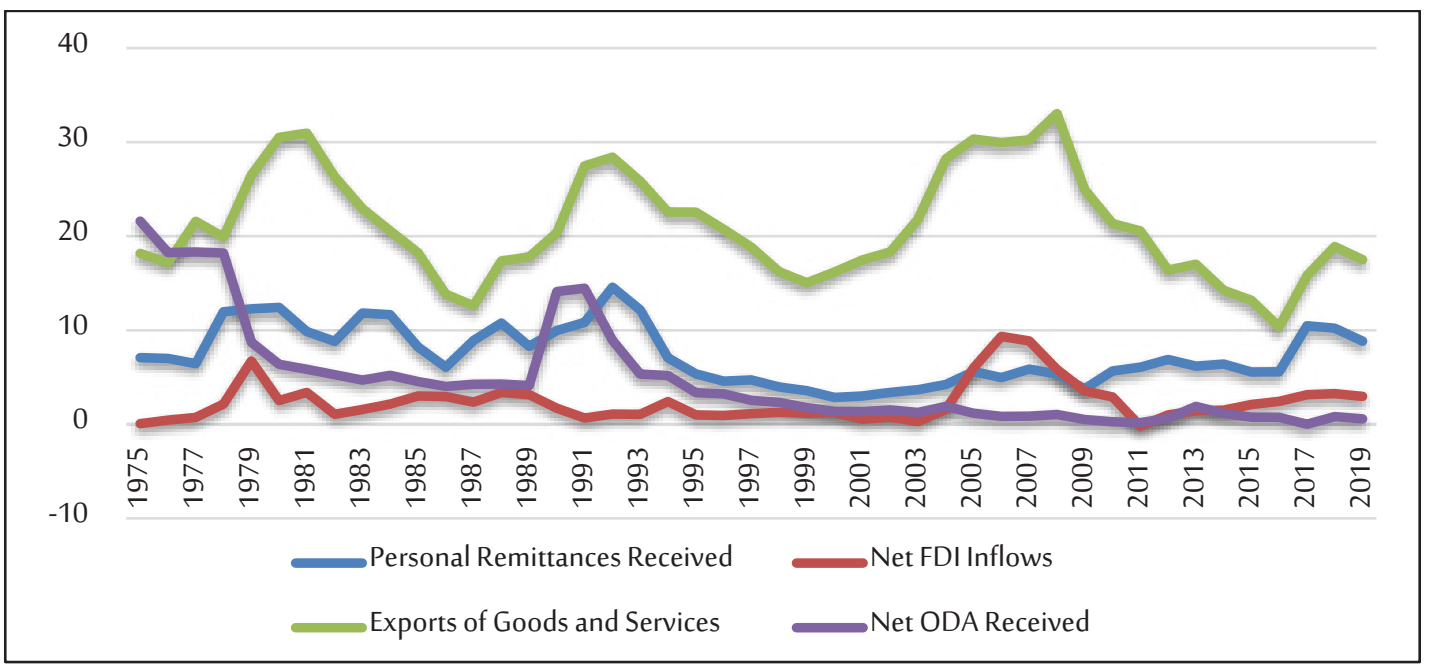

Source: World Bank, WDI

Figure (1) Sources of Foreign Exchange (\% of GDP)

Furthermore, it appears that remittances represent a relatively stable source of foreign exchange in the Egyptian economy compared to exports and net FDI inflows. According to figure (1), although exports and net FDI inflows have fallen due to the 2008 global financial crisis and political instability after January 2011, remittance inflows as a \% of GDP have increased in most of the years during 2009-2019, which confirms the relative stability of remittance inflows.

Such increasing importance of remittances as a source of foreign exchange in Egypt can be proved also by observing the trend of remittances as a $\%$ of imports and international reserves, as illustrated by figures (2) and (3) respectively. Figure (2) indicates that remittances have represented about $25 \%$ of imports on average during 1975-2019, whereas figure (3) shows that remittances as a \% of international reserves have averaged nearly $85 \%$ during 1975-2019.

Moreover, empirical evidence shows that remittances have contributed positively to economic growth in Egypt. For instance, Sharaf (2014) found using an ARDL model that remittances had a long-run positive impact on economic growth in Egypt during 1977-2012. The same conclusion has been reached by Naga (2015) using an ARDL model for the time period during 1975-2012.

Nevertheless, an in-depth investigation of remittance inflows to Egypt will show that there are several factors that determine the amount of remittance inflows, the motives for sending them, as well as how those inflows are spent. Thus, it is important to differentiate between such determinants of remittance inflows both at the micro and macro levels.

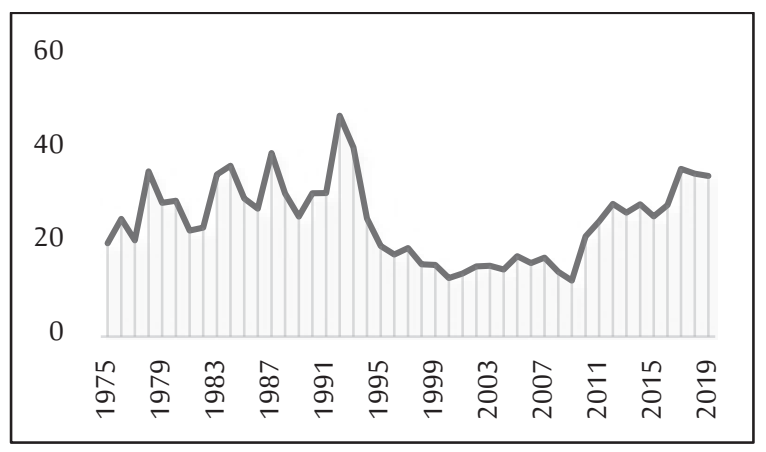

Source: World Bank, WDI

Figure (2) Remittances as a \% of Imports

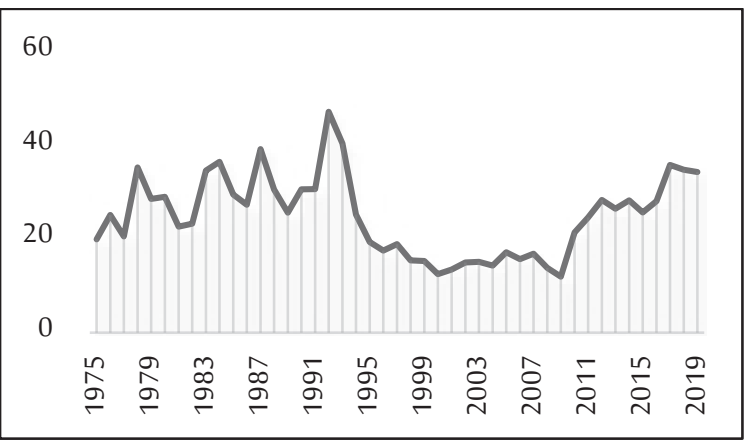

Source: World Bank, WDI

Figure (3) Remittances as a \% of International Reserves

At the micro level, the empirical studies adopted mainly qualitative data of the migrants and recipient families. For example, Jureidini et al. (2010) showed through interviews with 200 remittance-receiving 
households across four Egyptian governorates that $80 \%$ of recipient families use remittances for meeting their daily needs including health and education, whereas the remaining $20 \%$ of recipient families invest in some form and $50 \%$ of those who invest have directed their investment towards real estate. Similar results have been reached by Farzanegan et al. (2017) through interviews with 304 remittance-receiving households across 16 Egyptian governorates during May 2015-May 2016, as they observed that $85 \%$ of the respondents in the survey said that they do not invest remittances.

At the macro level, several empirical studies used quantitative data to investigate the macroeconomic determinants of remittance inflows to Egypt. For instance, Akçay and Karasoy (2019) found using an ARDL model that remittance inflows to Egypt were positively related to macroeconomic instability and oil prices during 1980-2015, whereas remittances inflows were not significantly associated with GDP growth in Egypt. Similarly, Qutb (2019) argued using an ARDL model that remittances are negatively associated with real exchange rate, real GDP per capita, and macroeconomic stability. The results of Akçay and Karasoy (2019) as well as Qutb (2019) indicate that remittance inflows to Egypt are counter-cyclical to output shocks.

\section{Trend and Determinants of Inflation in Egypt}

The review of inflation dynamics in Egypt shows that inflation rate has fluctuated largely depending on several determinants that differed from one sub-period to another. In this context, this sub-section will start with reviewing the inflation trend in Egypt during 1975-2019, and then identifying the main determinants of inflation through reviewing the empirical studies in that regard.

\section{1- Inflation Trend in Egypt}

During the second half of the 1970s as well as the whole 1980s, the monetary policy in Egypt was largely influenced by the fiscal policy, since the monetary policy instruments were mainly directed towards financing the rising budget deficit. Thus, the Central Bank of Egypt (CBE) was lacking independence in operating the monetary policy effectively to achieve price level stability (Abo El Eyoun, 2003). Consequently, the inflation rate was high with an average of 15.5\% during 1975-1991 and reached its peak in 1986 with $23.9 \%$ as shown in figure (4).

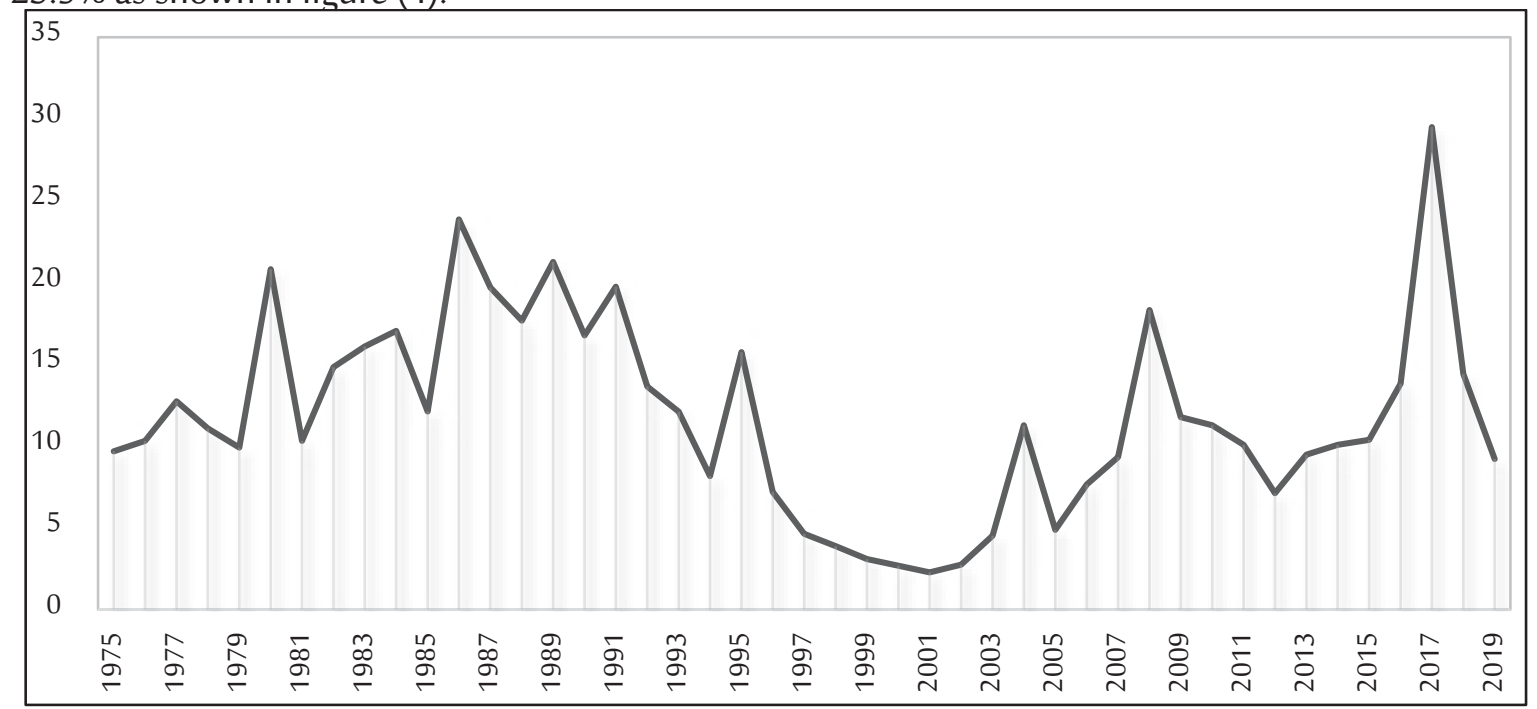

Source: World Bank, WDI

Figure (4) Inflation by Consumer Prices (annual \%)

By the early 1990s, the Government of Egypt (GoE) implemented the Economic Reform and Structural Adjustment Program (ERSAP) aiming at stabilizing the macroeconomic indicators and among these indica- 
tors was the inflation rate. Accordingly, the CBE started to adopt indirect monetary policy instruments to achieve price level stability and exchange rate stability. Meanwhile, the credit ceilings were abolished in the early 1990s. As a result of such reforms, the inflation rate declined to reach an average of $11.4 \%$ during 1992-1996 and the inflation rate was $7.2 \%$ in 1996 compared to $19.7 \%$ in 1991.

Starting from 1997, the Egyptian economy faced a liquidity crisis that was caused by both internal and external shocks. The internal shocks included mainly the large amount of bank loans given to the real estate sector as well as the largely growing public debt, whereas the external shocks involved the decline in foreign currency inflows from oil exports, tourism, Suez Canal, and workers' remittances (Moursi et al., 2007). Consequently, the inflation rate has declined to reach an average of 3.2\% during 1997-2002.

In January 2003, the CBE replaced an adjustable peg for the exchange rate with a floating exchange rate and the Egyptian pound lost $50 \%$ of its value resulting in an exchange rate pass-through effect. Consequently, the inflation rate has risen from $4.5 \%$ in 2003 to $11.3 \%$ in 2004.

Since 2005, the CBE has shifted towards inflation targeting with price level stability as the sole ultimate objective of the monetary policy, but the inflation rate remained high with an average of $10.5 \%$ during 2005-2010 due to several factors. Among these factors were the avian flu outbreak in 2006 and 2007, the surge in world food prices, the rise in domestic oil prices, and the fall in foreign currency inflows that followed the global financial crisis during 2007-2009 (Moriyama, 2011). In this context, the inflation rate surged from $4.9 \%$ in 2005 to $18.3 \%$ in 2008 before falling to $11.3 \%$ in 2010 .

Although the sub-period during 2011-2015 has been characterized by a decline in the economic activity due to the political instability that followed the Jan $25^{\text {th }}$ revolution in 2011 , the inflation rate reached $10.4 \%$ in 2015 compared to $7.1 \%$ in 2012 with an average of $9.4 \%$ during 2011-2015. Such relatively high inflation rate can be largely explained by the fall in the value of the Egyptian pound as a result of the decline in foreign currency inflows. In addition, this rise in the inflation rate might be explained also by the growing budget deficit resulting from the increased government spending for social reasons such as wage bill and subsidies after the Jan $25^{\text {th }}$ revolution.

The last sub-period during 2016-2019 witnessed a surge in inflation rate that reached a $16.7 \%$ on average with a record high of $29.5 \%$ in 2017 . Such rise in the inflation rate resulted mainly from the exchange rate pass-through effect that followed the adoption of a floating exchange rate in November 2016. Following such devaluation, the Egyptian pound lost about 78\% of its value during 2017 compared to 2016. However, as a result of the effective monetary policy management by the $C B E$, the inflation rate declined to $14.4 \%$ in 2018 and then to $9.2 \%$ in 2019.

\section{2- Inflation Determinants in Egypt}

The review of empirical studies of the inflation determinants in Egypt shows that the results of these studies varied depending on several factors such as the type of data, the time period under investigation, the adopted econometric estimation technique, and the variables included in the econometric model.

For instance, Ali (2011) analyzed the inflation dynamics in Egypt during 1980-2009 using a VAR model of monthly data. Although the results indicated that the inflation determinants have differed from one sub-period to another as previously illustrated in our analysis of the inflation trend in Egypt, the study argued that inflation persistence (lagged inflation) explained the largest portion of variation in inflation followed by monetary growth (money supply) and then supply-side shocks, whereas the exchange rate passthrough effect has just explained a small portion of changes in inflation.

Hosny (2013) used an ARDL model of monthly data during 2003-2012 to differentiate between the internal and external sources of inflation in Egypt. The long-run results of the model showed that monetary 
growth and global commodity prices were the main determinants of inflation, while the short-run determinants were inflation persistence, supply-side bottlenecks, and the exchange rate pass-through effect.

Furthermore, El Baz (2014) investigated the determinants of inflation in Egypt using a VAR model of annual data during 1991-2012. The results concluded that inflation is mostly driven in Egypt by inflation persistence followed by monetary growth, output gap, World food prices, and the exchange rate passthrough effect.

Alternatively, Abdelraouf et al. (2019) adopted an ARDL model of monthly data during January 2000-October 2018 to investigate the inflation dynamics in Egypt while focusing on the effect of relative price variability resulting from nominal price rigidities, less market competition, and administered prices. The results indicated that inflation was largely driven in the long run by money supply related to financing the budget deficit followed by relative price variability, whereas the exchange rate pass-through effect and supply-side shocks were transitory rather than being structural determinants of inflation.

Moreover, Abonazel and Elnabawy (2020) similarly argued using an ARDL model of quarterly data during 2005:Q1-2018:Q2 that the main sources of inflation in Egypt were monetary growth, inflation persistence, and the exchange rate pass-through effect, which complies with the results of the above-mentioned empirical studies.

Based on the results of the reviewed empirical studies, it can be concluded that the main determinants of inflation in Egypt are inflation persistence, monetary growth, and supply-side shocks which matches with Gordon's triangle model of inflation sources. However, it appears that such empirical studies have not included remittances among the inflation determinants in Egypt despite of the inflationary pressures that might result from the huge remittances flowing to the Egyptian economy. In this regard, this paper differs from the above-mentioned empirical studies as it includes remittances among the inflation determinants.

\section{Methodology}

This paper adopts ARDL cointegration approach to identify the short-run as well as the long-run sources of inflation in Egypt during 1975-2019 with special emphasis on remittances and its relationship with inflation.

\section{Model Specification and Data}

Based on the theoretical and empirical evidence on the determinants of inflation, the specified model included variables related to different sources of inflation such as output gap, money supply, remittances, exchange rate, and trade openness. The specified model of the inflation determinants takes the following form:

$$
\mathrm{CPI}=\mathrm{f}(\mathrm{GAP}, \mathrm{MON}, \mathrm{REM}, \mathrm{EXR}, \mathrm{OPEN})
$$

Where:

- $\quad C P I$ the consumer price index used as a proxy for inflation rate

- $\quad$ GAP the output gap calculated using the Hodrick-Prescott (HP) filter

- MON the money supply or broad money (M2)

- REM the remittance flows that include both personal transfers and compensation of employees

- $\quad$ EXR the nominal exchange rate of the Egyptian pound against the US dollar

- OPEN trade openness which is trade as a percentage of GDP 
The output gap is calculated using the Hodrick-Prescott (HP) filter which is a data smoothing technique that separates the long-run trend in a data series from the short-run fluctuations. The HP filter for GDP decomposes the real GDP growth into trend and cyclical components (De Jong and Sakarya, 2016). Here, the cyclical component represents the output gap which is the difference between the actual series of real GDP growth and its long-run trend (Hosny, 2013).

The source for the annual data of the nominal exchange rate was the $C B E$, while the annual data for the remaining variables were extracted from the WDI by the World Bank. All the variables were represented in their natural logarithms except the output gap, since the output gap might have negative values if real GDP growth is below its long-run trend.

\section{Econometric Technique}

According to recent literature in econometrics, most time series are not stationary implying that that the means and variances of the variables are not constant and depend on time. In this context, the OLS estimation of such non-stationary time series will result in spurious regression with misleading conclusions. In order to avoid this problem of spurious regression, econometrics has moved towards cointegration technique. Cointegration detects whether there is a long-run equilibrium relationship between the non-stationary variables (Nkoro and Uko, 2016). Here, we can distinguish between Engle-Granger cointegration approach, Johansen cointegration approach, and ARDL cointegration approach which is also known as the bounds testing approach.

According to Pesaran and Shin (1999), the performance of ARDL approach is better if the sample size is small or finite. Furthermore, Pesaran et al. (2001) suggested that using ARDL approach is applicable regardless of whether the variables are purely integrated of order zero, $I(0)$, or purely integrated of order one, $I(1)$, or a mixture of $I(0)$ and $I(1)$ variables. This is unlike to the Engle-Granger and Johansen approaches, since both approaches are concentrating only on variables that are I(1).

Consequently, the ARDL cointegration approach will be adopted in this paper since its requirements are fulfilled. Firstly, the sample size is finite covering the annual data during 1975-2019. Secondly, the variables under consideration represent a mixture of $I(0)$ and $I(1)$ variables as shown in section (5).

The ARDL cointegration approach starts with testing for the stationarity of the variables using unit root tests such as the Augmented-Dickey Fuller (ADF) and Phillips-Perron (PP) tests. If the variables were a mixture of $I(0)$ and $I(1)$ variables, then the autoregressive distributed lag-unrestricted error correction (ARDL-UECM) model is estimated using OLS where the lagged differences and lagged levels of all the variables are included in the model in the following form:

$$
\begin{aligned}
& \Delta \operatorname{lnCPI_{t}}=\alpha_{0}+\sum_{i=1}^{P} \alpha_{1 i} \Delta \ln C P I_{t-i}+\sum_{i=0}^{q_{1}} \alpha_{2 i} \Delta G A P_{t-i}+\sum_{i=0}^{q_{2}} \alpha_{3 i} \Delta \ln M O N_{t-i} \\
& +\sum_{i=0}^{q_{3}} \alpha_{4 i} \Delta \ln R E M_{t-i}+\sum_{i=0}^{q_{4}} \alpha_{5 i} \Delta \ln E X R_{t-i}+\sum_{i=0}^{q_{5}} \alpha_{6 i} \Delta \operatorname{lnOPEN_{t-i}} \\
& +\beta_{1} \ln C P I_{t-1}+\beta_{2} G A P_{t-1}+\beta_{3} \ln M O N_{t-1}+\beta_{4} \ln R E M_{t-1} \\
& +\beta_{5} \ln E X R_{t-1}+\beta_{6} \ln O P E N_{t-1}+\varepsilon_{t}---(6)
\end{aligned}
$$

The optimal lag levels $\left(p, q_{1} q_{z^{\prime}} q_{3^{\prime}} q_{4} q_{5}\right)$ for the above ARDL-UECM is selected based on the lag length criteria such as Akaike Information Criterion (AIC) or Schwarz Criterion (SC), where the selected model is the one with least value for the criterion. 
In the next step, the existence of cointegration between the model variables is tested using the bounds testing approach proposed by Pesaran et al. (2001). According to the bounds testing approach, the significance of the lagged levels of the regressors is tested using the F-statistic where there are two sets of asymptotic critical values that define two bounds, which are the lower bound and the upper bound.

The lower bound assumes that all variables are $I(0)$, while the upper bound assumes that all variables are I(1). If the computed F-statistic for all the lagged levels of the regressors is above the critical value for the upper bound, it can be concluded that the regressors are cointegrated. Conversely, if the computed F-statistic is below the critical value for the lower bound, then the regressors are not cointegrated. Finally, if the computed F-statistic is between the critical values for the lower and upper bounds, the inference will be not conclusive in this case.

In the bounds test, the null hypothesis $\left(\mathrm{H}_{0}\right)$ is that there is no long-run relationship between regressors (there is no cointegration) and the alternative hypothesis $\left(\mathrm{H}_{1}\right)$ is that there is a long-run relationship between the regressors (there is cointegration) as shown below:

$$
\begin{aligned}
& H_{0}: \beta_{1}=\beta_{2}=\cdots=\beta_{6}=0 \\
& H_{1}: \beta_{1} \neq \beta_{2} \neq \cdots-\beta_{6} \neq 0
\end{aligned}
$$

If the null hypothesis of the bounds test is rejected, this implies that variables are cointegrated and thus we can proceed with estimating the long-run coefficients using the conditional ARDL model $\left(p, q_{1} q_{1^{\prime}} q_{3^{\prime}} q_{4}\right.$ $q_{5}$ ) which will take the following form:

$$
\begin{aligned}
\ln C P I_{t}=\beta_{0} & +\sum_{i=1}^{P} \beta_{1} \ln C P I_{t-1}+\sum_{i=0}^{q_{1}} \beta_{2} G A P_{t-1}+\sum_{i=0}^{q_{2}} \beta_{3} \ln \operatorname{MON}_{t-1} \\
& +\sum_{i=0}^{q_{3}} \beta_{4} \ln R E M_{t-1}+\sum_{i=0}^{q_{5}} \beta_{5} \ln E X R_{t-1}+\sum_{i=0}^{q_{4}} \beta_{6}{\ln O P E N_{t-1}+\mu_{t}}^{----(7)}
\end{aligned}
$$

Finally, an error correction model (ECM) is estimated using OLS to represent the short-run dynamics of the model in the form of the lagged differences of the variables in addition to an error correction term $\left(E C T_{t-1}\right)$ that shows the speed of adjustment of the variables towards the long-run equilibrium. The conditional $\operatorname{ECM}\left(p, q_{1}, q_{2}, q_{3^{\prime}} q_{4}, q_{5}\right)$ will take this form:

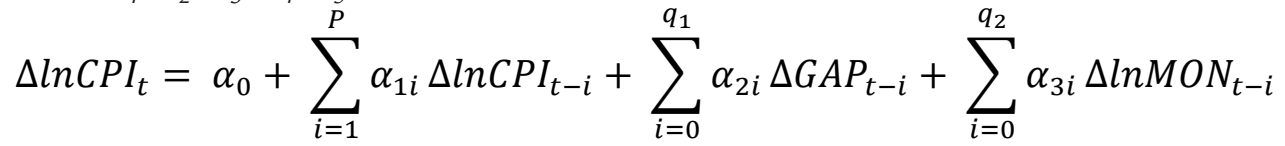

$$
\begin{aligned}
& +\sum_{i=0}^{q_{3}} \alpha_{4 i} \Delta \ln R E M_{t-i}+\sum_{i=0}^{q_{4}} \alpha_{5 i} \Delta \ln E X R_{t-i}+\sum_{i=0}^{q_{5}} \alpha_{6 i} \Delta \operatorname{lnOPEN_{t-i}} \\
& +\lambda E C T_{t-1}+\varepsilon_{t}----(8)
\end{aligned}
$$

In the above ECM, the coefficient of the error correction term $(\lambda)$ shows how much of the divergence from the long-run equilibrium in the previous time period $(t-1)$ is being adjusted in the current time period (t). A negative and statistically significant $\lambda$ indicates that a convergence of the variables towards the longrun equilibrium, whereas a positive $\lambda$ indicates a divergence from the long-run equilibrium (Nkoro and Uko, 2016). 


\section{Results}

Before running the regression, the time series are checked to identify their order of integration using the ADF and PP unit root tests and the results of both tests are reported in tables (1) and (2) respectively using EViews 10. The results of both tests show that the time series variables represent a mixture of $I(0)$ and $I(1)$, indicating that the ARDL approach to cointegration is the appropriate approach in this case.

The ARDL model is then estimated using OLS with optimal lags as an ARDL $(1,0,3,3,1,3)$ based on the Akaike Information Criterion (AIC) for model selection. Now, the model variables will be tested for cointegration using the bounds test proposed by Pesaran et al. (2001). The results reported in table (3) indicate that cointegration exists between the variables; that is, there is a long-run relationship between the variables in their levels, since the F-statistic of the bounds test is equal to 13.67 which is above the critical values of the upper bound at all levels of significance.

Long-run results of the conditional ARDL model are reported in table (4). Long-run results show that the coefficient for remittance inflows is positive and statistically significant with a $1 \%$ increase in remittance inflows leading to about $0.64 \%$ increase in the inflation rate, implying that remittance inflows have inflationary pressures in the long run. This result is consistent with the results of most empirical studies such as Nisar and Tufail (2013), Ngoc and Nguyen (2014), and Abdul-Mumni and Quaido (2016).
Table 1

Results of ADF Unit Root Test

\begin{tabular}{|c|c|c|c|c|c|}
\hline \multirow[b]{2}{*}{ Variable } & \multicolumn{2}{|c|}{ Level } & \multicolumn{2}{|c|}{ First Difference } & \multirow[b]{2}{*}{$\begin{array}{c}\text { Order of } \\
\text { Integration }\end{array}$} \\
\hline & Intercept & $\begin{array}{l}\text { Trend and } \\
\text { Intercept }\end{array}$ & Intercept & $\begin{array}{l}\text { Trend and } \\
\text { Intercept }\end{array}$ & \\
\hline $\operatorname{lnCPI}$ & -1.2383 & -1.8549 & $-3.3234^{* *}$ & $-3.4353^{*}$ & $\mathrm{I}(1)$ \\
\hline GAP & $-5.0662^{* * *}$ & $-6.5362^{* * *}$ & $-13.877^{* * *}$ & $-13.756^{* * *}$ & $\mathrm{I}(0)$ \\
\hline $\operatorname{lnMON}$ & -2.5917 & -2.3417 & $-4.9826^{* * *}$ & $-5.3029 * * *$ & $\mathrm{I}(1)$ \\
\hline InREM & -0.8941 & -1.7649 & $-6.5151^{* * *}$ & $-6.4351^{* * *}$ & $\mathrm{I}(1)$ \\
\hline $\ln E X R$ & -0.9984 & -2.9524 & $-4.3403^{* * *}$ & $-4.2741^{* * *}$ & $\mathrm{I}(1)$ \\
\hline InOPEN & $-3.3312^{* *}$ & $-4.7811^{* * *}$ & $-5.6287^{* * *}$ & $-5.5650 * * *$ & $\mathrm{I}(0)$ \\
\hline
\end{tabular}

*** Significant at $1 \%$, $* *$ Significant at $5 \%$, Significant at $10 \%$

Null Hypothesis: The series contains a unit root

Reported values represent the t-statistics

Table (2)

Results of PP Unit Root Test

\begin{tabular}{|c|c|c|c|c|c|}
\hline \multirow[b]{2}{*}{ Variable } & \multicolumn{2}{|c|}{ Level } & \multicolumn{2}{|c|}{ First Difference } & \multirow[b]{2}{*}{$\begin{array}{c}\text { Order of } \\
\text { Integration }\end{array}$} \\
\hline & Intercept & $\begin{array}{l}\text { Trend and } \\
\text { Intercept }\end{array}$ & Intercept & $\begin{array}{l}\text { Trend and } \\
\text { Intercept }\end{array}$ & \\
\hline $\ln C P I$ & -1.1210 & -1.5561 & $-3.2921 * *$ & $-3.4235^{*}$ & $\mathrm{I}(1)$ \\
\hline GAP & $-7.3676^{* * *}$ & $-7.2815^{* * *}$ & $-24.741^{* * *}$ & $-24.595^{* * *}$ & $\mathrm{I}(0)$ \\
\hline $\operatorname{lnMON}$ & -2.4629 & -2.4051 & $-4.9516^{* * *}$ & $-5.2689 * * *$ & $\mathrm{I}(1)$ \\
\hline InREM & -0.8653 & -1.7649 & $-6.5255^{* * *}$ & $-6.4404 * * *$ & $\mathrm{I}(1)$ \\
\hline $\ln E X R$ & -0.6467 & -1.8843 & $-4.1864 * * *$ & $-4.1687^{* * *}$ & $\mathrm{I}(1)$ \\
\hline InOPEN & -2.4698 & -2.7064 & $-5.6485^{* * *}$ & $-5.5861^{* * *}$ & $\mathrm{I}(1)$ \\
\hline
\end{tabular}

*** Significant at $1 \%$, $*$ Significant at $5 \%$, Significant at $10 \%$

Null Hypothesis: The series contains a unit root

Reported values represent the adjusted t-statistics

Table (3)

Results of Bounds Test

\begin{tabular}{|c|c|c|c|c|}
\hline \multirow{2}{*}{$\begin{array}{c}\text { Test } \\
\text { Statistic }\end{array}$} & \multirow{2}{*}{ Value } & \multirow{2}{*}{$\begin{array}{c}\text { Significance } \\
\text { Level }\end{array}$} & \multicolumn{2}{|c|}{ Critical Values } \\
\hline & & & $I(0)$ Bound & I(1) Bound \\
\hline \multirow{2}{*}{ F-statistic } & \multirow{2}{*}{13.67} & \multicolumn{3}{|c|}{ Finite Sample: $\mathrm{n}=45$} \\
\hline & & $10 \%$ & 2.458 & 3.647 \\
\hline $\mathrm{K}$ & 5 & $5 \%$ & 2.922 & 4.268 \\
\hline \multirow{5}{*}{$\begin{array}{l}\text { Actual } \\
\text { Sample } \\
\text { size }\end{array}$} & \multirow[t]{5}{*}{42} & $1 \%$ & 4.030 & 5.598 \\
\hline & & \multicolumn{3}{|c|}{ Finite Sample: $\mathrm{n}=40$} \\
\hline & & $10 \%$ & 2.483 & 3.708 \\
\hline & & $5 \%$ & 2.962 & 4.338 \\
\hline & & $1 \%$ & 4.045 & 5.898 \\
\hline
\end{tabular}

Null Hypothesis: No levels relationship

Such inflationary pressures caused by remittance inflows to Egypt in the long run can be explained by the results of the empirical studies on the determinants of remittance inflows to Egypt such Jureidini et al. (2010) and Farzanegan et al. (2017) which concluded that the majority of remittance inflows to Egypt are spent on consumption rather than being directed to investment in productive sectors. Furthermore, the results of Akçay and Karasoy (2019) as well as Qutb (2019) argued that remittance inflows to Egypt are counter-cyclical to output shocks and thus, are sent for altruistic motives rather than investment purposes, given that the remittances sent for altruistic motives are mainly spent on consumption.

Since the output gap is not log transformed while the CPI is log transformed, we will exponentiate the coefficient for output gap and then subtract one from this number and multiply by 100 to get the percent 
increase in the inflation rate for every one-unit increase in the output gap, which will be equal to about $6 \%$ in this case. This positive and statistically significant coefficient for output gap implies that an increase in real GDP above its trend will be associated with inflationary pressures from the demand side. Meanwhile, money supply has a positive and statistically significant coefficient with a $1 \%$ increase in money supply leading to about $0.69 \%$ increase in the inflation rate, and this result complies with the empirical studies on the sources of inflation in Egypt.

Moreover, openness has a positive and statistically significant coefficient with a $1 \%$ increase in openness resulting in about $1.2 \%$ increase in the inflation rate, and this can be explained by the fact that Egypt is a largely importing country and thus, the rise in import prices will increase the inflationary pressures. Although, exchange rate has a positive coefficient but it is statistically insignificant, implying that there is no evidence of the exchange rate pass-through effect in the long run in the Egyptian economy.

Short-run results as represented by the ECM are reported in table (5). Unlike the long-run results, remittance inflows have a negative and statistically significant effect on inflation with a lag of one and two years, and this result might be due to the rise in foreign currency inflows caused by remittances which, in turn, result in an appreciation in the value Egyptian pound. Such appreciation in the value of the Egyptian pound leads to a fall in the imports bill in the short run, and thus a decrease in the inflation rate. Such result matches with the results of empirical studies such as Narayan et al. (2011), Khan and Islam (2013), and Abdul-Mumni and Quaido (2016) which argued that the positive effect of remittances on inflation was not confirmed in the short run.

Other short run results indicate that the exchange rate has inflationary pressures, since the coefficient for exchange rate shows that every $1 \%$ increase in nominal exchange rate results instantaneously in about $0.1 \%$ increase in the inflation rate. The effect of openness on inflation in the short run indicates that it has a positive statistically significant effect instantaneously confirming with the long-run results and a negative statistically significant effect with a lag of two years. Such negative effect of openness can be explained by the increased efficiency and competitiveness caused by trade openness which, in turn, decrease the inflationary pressures.

Finally, the error correction term has a negative and statistically significant coefficient which indicates convergence towards long-run equilibrium with about $13 \%$ of the disequilibrium is being adjusted each year as suggested by the coefficient of the error correction term which is equal to -0.1283 . In other words, it takes about 8 years for the variables to converge towards long-run equilibrium which is considered a slow adjustment. This result is expected since most of the empirical studies have concluded that inflation persistence is considered among the main sources of inflation in Egypt, implying that past inflation rates play an important role in determining current inflation rate in the short run due of the lack of confidence by the public in the monetary policy's commitment towards inflation targeting.
Table (5)

Short-Run Results: Error Correction Model Dependent variable: $\Delta / n C P{ }_{t}$

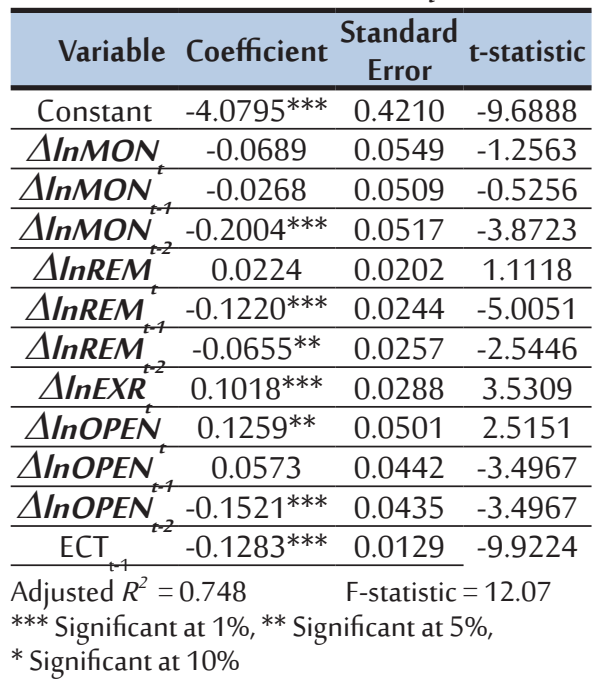

* Significant at $10 \%$ 
The value of adjusted $R^{2}$ indicates that about $75 \%$ of the changes in inflation rate is explained by changes in the independent variables included in the model. Meanwhile, the model is significant as the F-statistic was equal to 12.07 . Moreover, the results of diagnostic tests for the model, as reported in table (6), show that the normality assumption is satisfied and that the model is well specified with no serial correlation and heteroskedasticity problems.

Furthermore, the stability of the model is tested. Figures (5) and (6) confirm that the model satisfies the stability condition, since the sum and cumulative sum of squares of recursive residuals lie between the lower and upper bounds implying that there is no root lying outside the significance level.

\section{Conclusion}

Remittances represent an important source of foreign exchange in the Egyptian economy. Nevertheless, empirical evidence shows that remittance inflows might have inflationary pressures in the recipient country. Thus, this paper uses an ARDL model to identify the source of inflation in Egypt during 1975-2019, while including remittances among the inflation determinants.

The results show that remittance inflows have inflationary pressures in the long run, and such result can be explained by the conclusion reached by some empirical studies that remittance inflows to Egypt are mainly directed towards consumption rather than investment in productive sectors. However, the short-run results indicate that remittance inflows might have deflationary pressures, and this result matches with other empirical studies on some developing countries which argued that the inflationary pressures caused by remittances are not confirmed in the short run.

Furthermore, the results on sources of inflation in the long run in addition to other than remittances are consistent with most empirical studies on the determinants of inflation in Egypt. Other sources of inflation in the long run include the output gap, money supply, and openness, whereas exchange rate passthrough effect is transitory as it exists only in the short run. Accordingly, there are some recommendations that might help contain inflationary pressures of remittances in the long run. Among these recommendations are implementing information campaigns that target Egyptian emigrants on the available investment opportunities in Egypt, creating financial products that are customized for Egyptian emigrants, reducing the regulative burdens on investment in Egypt, and providing more incentives for Egyptian emigrants to invest in productive sectors not just the real state sector.
Table (6)

Results of Diagnostic Tests

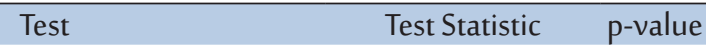

Jarque-Bera = 1.75850 .4151

F-statistic $=1.5088 \quad 0.1733$

t-statistic $=0.5421 \quad 0.5928$

F-statistic $=0.2938 \quad 0.5928$

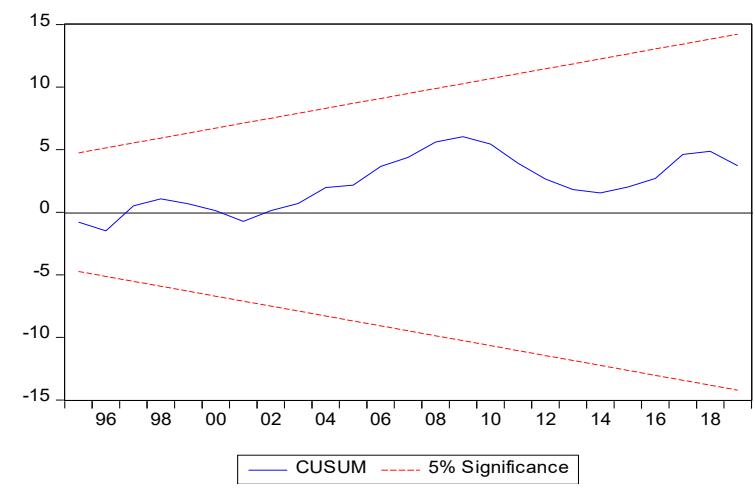

Figure (5) Cumulative Sum of Recursive Residuals

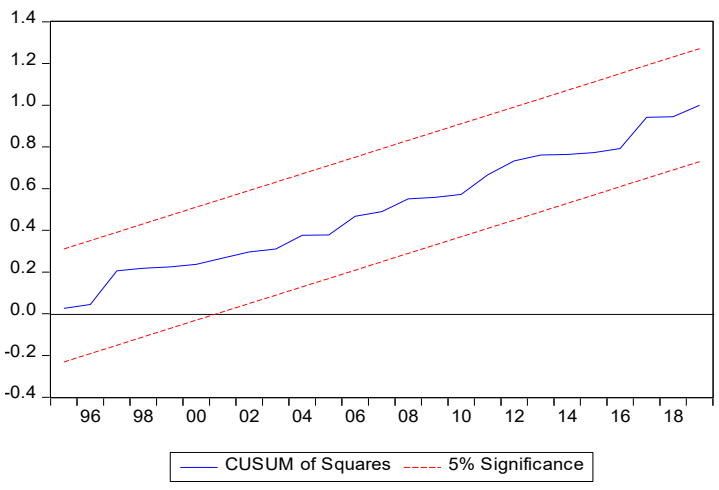

Figure (6) Cumulative Sum of Squares of Recursive Residuals 


\section{References}

Abdelraouf, N., El-Abbadi, H., \& Noureldin, D. (2019). Inflation Dynamics in Egypt: Structural Determinants versus Transitory Shocks. Working Paper, 201, The Egyptian Center for Economic Studies.

- $\quad$ Abdul-Mumni, A., \& Quaido, C. (2016). "Effect of International Remittances on Inflation in Ghana Using the Bounds Testing Approach". Business and Economic Research, 6(1), 192-209.

- $\quad$ Abo El Eyoun, M. A. (2003). Monetary Policy Developments in Arab Republic of Egypt and the Future Directions. Working Paper, 78, The Egyptian Center for Economic Studies (In Arabic).

- $\quad$ Abonazel, M. R., \& Elnabawy, N. (2020). “Using the ARDL Bound Testing Approach to Study the Inflation Rate in Egypt". Economic Consultant, 31(3), 24-42.

- $\quad$ Acosta, P. A., Lartey, E. K., \& Mandelman, F. S. (2009). Remittances and the Dutch Disease. Working Paper, 2007-8a, Federal Reserve of Atlanta.

- $\quad$ Akçay, S., \& Karasoy, A. (2019). “Determinants of Remittances in Egypt: Do Macroeconomic Instability and Oil Price Matter?". International Migration, 57(5), 142-160.

- $\quad$ Ali, H. (2011). Inflation Dynamics: The Case of Egypt. MPRA Paper No. 36331, Munich Personal RePEc Archive.

- $\quad$ Amuedo-Dorantes, C., \& Pozo, S. (2004). “Workers' Remittances and the real Exchange Rate: A Paradox of Gifts". World Development, 32(8), 1407-1417.

- $\quad$ Balderas, J. U., \& Nath, H. K. (2008). "Inflation and Relative Price Variability in Mexico: The Role of Remittances". Applied Economic Letters, 15(3), 181-185.

- $\quad$ Ball, C. P., Lopez, C., \& Reyes, J. (2013). “Remittances, Inflation, and Exchange Rate Regimes in Small Open Economies". The World Economy, 36(4), 487-507.

- Benkovskis, K., Caivano, M., D’Agostino, A., Dieppe, A., Hurtado, S., Karlsson, T., Ortega, E., \& Várnai, T. (2011). Assessing the Sensitivity of Inflation to Economic Activity. Working Paper Series, 1357, European Central Bank.

- $\quad$ Cáceres, L. R., \& Saca, N. N. (2006). What Do Remittances Do? Analyzing the Private Remittance Transmission Mechanism in El Salvador. IMF Working Papers, 06/250, International Monetary Fund.

- $\quad$ De Jong, R. M., \& Sakarya, N. (2016). "The Econometrics of the Hodrick-Prescott Filter". The Review of Economics and Statistics, 98(2), 310-317.

- $\quad$ El Baz, O. (2014). The Determinants of Inflation in Egypt: An Empirical Study (1991-2012). MPRA Paper No. 56978, Munich Personal RePEc Archive.

- $\quad$ Farzanegan, M. R., Hassan, S. M., \& Raad, R. A. (2017). Causes ad Impacts of Remittances: Household Survey Evidence from Egypt. Joint Discussion Paper Series in Economics, 37-2017, The Universities of Aachen, Gieben, Göttingen, Kassel, Marburg, \& Siegen.

- $\quad$ Friedman, M. (1968). The Role of Monetary Policy. The American Economic Review, 58(1), 1-17.

- $\quad$ Froyen, R. T. (2013). Macroeconomics: Theories and Policies. $10^{\text {th }}$ ed. Essex: Pearson Education Limited.

- Hosny, A. (2013). "Inflation in Egypt: Internal or External Driven?". Middle East Development Journal, 5(3), 1350019/1-1350019/15.

- $\quad$ IMF. (2009). Balance of Payments and International Investment Manual, 6th ed. (BPM6). Washington, D.C.: International Monetary Fund.

- $\quad$ Iqbal, J., Nosheen, M., \& javed, A. (2013). "The Nexus between Foreign Remittances and Inflation: Evidence from Pakistan". Pakistan Journal of Social Sciences, 33(2), 331-342.

Jordon, R. J. (1990). The Phillips Curve Now and Then. NBER Working Papers, 3393, National Bureau of Economic Research. 
Jureidini, R., Bartunkova, I., Ghoneim, A., Ilahi, N., \& Ayjin, E. (2010). A Study on Remittances and Investment Opportunities for Egyptian Migrants. Cairo: International Organization for Migration.

- Khan, Z. S., \& Islam, S. (2013). "The Effects of Remittances on Inflation: Evidence from Bangladesh". Journal of Economics and Business Research, 19(2), 198-208.

- Kibritçioğlu, A. (2002). Causes of Inflation in Turkey: A Literature Survey with Special Reference to Theories of Inflation. In A. Kibritçioğlu, F. Selçuk, L. Rittenberg (Eds.), Inflation and Disinflation in Turkey. Hampshire: Ashgate Publication Limited, 43-76.

- $\quad$ Lartey, E. K., Mandelman, F. S., \& Acosta, P. A. (2008). Remittances, Exchange Rate Regimes, and the Dutch Disease: A Panel Data Analysis. Working Paper, 2008-12, Federal Reserve Bank of Atlanta.

- $\quad$ Lipsey, R. G. (1960). "The Relation between Unemployment and the Rate of Change of Money Wage Rates in the United Kingdom, 1862-1957: A Further Analysis". Economica, 27(105), 1-31.

Moriyama, K. (2011). Inflation Inertia in Egypt and its Policy Implications. IMF Working Papers, 11/160, International Monetary Fund.

Moursi, T. A., El Mossallamy M., \& Zakareya E. (2007). Effect of Some Recent Changes in Egyptian Monetary Policy: Measurement and Evaluation. Working Paper, 122, The Egyptian Center for Economic Studies.

- Naga, A. A. (2015). "The Impact of Remittances on Economic Growth in Egypt during the Period (19752012): Econometric Analytical Study". Journal of the Faculty of Commerce for Scientific Research, Alexandria University, 52(1), 1-43 (In Arabic).

Narayan, P. K., Narayan, S., \& Mishra, S. (2011). “Do Remittances Induce Inflation? Fresh Evidence from Developing Countries". Southern Economic Journal, 77(4), 914-933.

- Ngoc, H. T., \& Nguyen, M. (2014). “Do Workers' Remittances Induce Inflation?”. The Case of Vietnam, 1996-2012. Review of Business and Economic Studies, 2(1), 39-48.

- Nisar, A., \& Tufail, S. (2013). "An Analysis of Relationship between Remittances and Inflation in Pakistan“. Zagreb International Review of Economics and Business, 16(2), 19-38.

- $\quad$ Nkoro, E., \& Uko, A. K. (2016). “Autoregressive Distributed Lag (ARDL) Cointegration Technique: Application and Interpretation". Journal of Statistical and Econometric Methods, 5(4), 63-91.

- $\quad$ Pesaran, M. H., \& Shin, Y. (1999). An Autoregressive Distributed Lag Modeling Approach to Cointegration Analysis. In S. Strom, S. Holly, \& P. Diamond (Eds.), Centennial Volume of Ragnar Frisch. Cambridge: Cambridge University Press, 371-413.

- $\quad$ Pesaran, M. H., Shin, Y., \& Smith, R. J. (2001). "Bounds Testing Approaches to the Analysis of Level Relationships". Journal of Applied Econometrics, 16(3), 289-326.

- $\quad$ Phillips, A. W. (1958). "The Relation between Unemployment and the Rate of Change of Money Wage rates in the United Kingdom, 1861-1957". Economica, 25(100), 283-299.

- $\quad$ Qutb, R. (2019). The Macroeconomic Determinants of Migrants' Remittances in Egypt: An ARDL Bounds Testing Approach. Proceedings of 267th IIER International Conference, (pp. 15-20). London.

- $\quad$ Rivera, J. p., \& Tuallo Jr., T. S. (2020). "Investigating the Link between Remittances and Inflation: Evidence from the Philippines". South East Asia Research, 28(3), 301-326.

- Samuelson, P. A., \& Solow, R. M. (1960). “Analytical Aspects of Anti-Inflation Policy". The American Economic Review, 50(2), 177-194.

- $\quad$ Sharaf, M. F. (2014). "The Remittances-Output Nexus: Empirical Evidence from Egypt”. Economics Research International, 1-8.

- $\quad$ Snowdon, B., \& Vane, H. R. (2005). Modern Macroeconomics. Northampton: Edward Elgar Publishing Limited.

Zahran, M. S. (2019). "The Response of Remittances Inflows to Asymmetric Oil Price Shocks in Egypt". Review of Economics and Political Science, https://doi.org/10.1108/REPS-01-2019-0009. 
